\title{
Induction of TGF- $\beta$ by Irradiation or Chemotherapy in Fanconi Anemia (FA) Mouse Bone Marrow Is Modulated by Small Molecule Radiation Mitigators JP4-039 and MMS350
}

\author{
MICHAEL W. EPPERLY ${ }^{1}$, BYUNG-HAN RHIEU ${ }^{1}$, DARCY FRANICOLA ${ }^{1}$, TRACY DIXON ${ }^{1}$, SHAONAN CAO ${ }^{1}$, \\ XICHEN ZHANG ${ }^{1}$, DONNA SHIELDS ${ }^{1}$, HONG WANG $^{1}$, PETER WIPF $^{2}$ and JOEL S. GREENBERGER ${ }^{1}$ \\ ${ }^{1}$ Department of Radiation Oncology, University of Pittsburgh Cancer Institute, Pittsburgh, PA, U.S.A.; \\ ${ }^{2}$ Department of Chemistry, University of Pittsburgh, Pittsburgh, PA, U.S.A.
}

\begin{abstract}
Background/Aim: Total-body irradiation and/or administration of chemotherapy drugs in bone marrow transplantation induce cytokines that can suppress engraftment. Fanconi Anemia (FA) patients have a hyperactive responsiveness to the inhibitory cytokine, transforming growth factor-beta (TGF- $\beta)$. Small molecule radiation mitigator drugs, JP4-039 and MMS350, were evaluated for suppression of irradiation or drug-induced TGF- $\beta$. Materials and Methods: In vivo induction of TGF- $\beta$ by total-body ionizing irradiation (TBI), L-phenylalanine mustard (L-PAM), busulfan or fludarabine, was quantified. In parallel, mitigator drug amelioration of TGF- $\beta$ induction in FA D2 $2^{-/-}\left(F_{\left.A N C D 2^{-l-}\right)}\right.$ mouse bone marrow, was studied in vitro. Tissue culture medium, cell lysates, and mouse plasma were analyzed for TGF- $\beta$ levels. Results: Induction of TGF- $\beta$ levels in FANCD2 $2^{-/-}$and FANCD2 $2^{+/}$mice and in mouse bone marrow were modulated by both JP4-039 and MMS350. Conclusion: Bone marrow transplantation in FA recipients may benefit from administration of small molecule agents that suppress TGF- $\beta$ induction.
\end{abstract}

Bone marrow transplantation is an established therapy for Fanconi anemia (FA) patients (1-4) that can result in a significant improvement in survival following donor bone

This article is freely accessible online.

Correspondence to: Joel S. Greenberger, MD, F.A.C.R.O., F.A.C.R., Professor and Chairman, Department of Radiation Oncology, University of Pittsburgh Cancer Institute, 5150 Centre Avenue, Rm. 533, Pittsburgh, Pennsylvania, 15232, U.S.A. Tel: +1 412 6473602, Fax: +1 412 6476029, e-mail: greenbergerjs@ upmc.edu

Key Words: TGF- $\beta$, total body irradiation, chemotherapy drugs, Fanconi Anemia, mouse bone marrow, molecular radiation, mitigators, JP4-039, MMS350. marrow engraftment (4). Critical to the success of marrow engraftment has been the application of chemotherapeutic agents as a preparatory regimen for marrow transplant that minimize toxicity to the host (3).

FA patients have previously been demonstrated to have a hyperactive TGF- $\beta$ response pathway (5), which may be a major cause of their initial marrow failure leading to anemia, as well as their sensitivity to the regimens used to prepare for bone marrow transplantation (1-4, 6-9). FA patients are also susceptible to late post-transplant induction of leukemia and solid tumors (7-15). DNA cross-linking agents such as mitomycin-C (14), other chemotherapeutic agents and irradiation induce DNA double strand breaks and must be delivered very cautiously to FA patients. The TGF- $\beta$ signaling pathway alters both baseline and post-marrow transplant hematopoiesis in FA patients and in FA animal models (16-23). The chemotherapy drug, fludarabine $(6,24-25)$, has facilitated bone marrow engraftment in FA patients, who are fragile in responsiveness to agents used in preparation for marrow transplantation (1-4, 6-9). We hypothesized that agents, which ameliorate the toxicity of total-body irradiation and/or chemotherapy drugs that may reduce the induction of TGF- $\beta$ (26-33) might decrease toxicity and improve engraftment in FA patient transplant recipients. Furthermore, improvement in survival of patients with FA (4) might be achieved by reduction in the toxicity of marrow transplant.

In this study, FANCD2 $2^{-/-}$mice were used for in vitro testing of the effects of two potential modulators (JP4-039 and MMS350) of the toxicity of irradiation or each of three chemotherapeutic drugs on TGF- $\beta$ induction in hematopoietic progenitor cells. FANCD2 $2^{-/-}$mouse marrow hematopoietic progenitors in vitro and stromal cell lines derived from the hematopoietic microenvironment (34) were used for TGF- $\beta$ induction by irradiation and chemotherapy drugs. We also tested the effect of JP4-039 and MMS350 on TGF- $\beta$ induction in plasma of TBI irradiated or drug-treated FANCD2 $2^{-/-}$(C57BL/6 background) mice. 
We evaluated the effect of radiation mitigator drugs JP4-039 (29) and MMS350 (32) as well as of the chemotherapeutic agents, L-phenylalanine mustard (L-PAM), busulfan and Fludarabine, on TGF- $\beta$ induction. The results demonstrated that TGF- $\beta$ expression was inducible by irradiation and by either of the three chemotherapeutic drugs in vitro and in vivo. In FANCD $2^{-/-}$mouse marrow in vitro and in mouse plasma in vivo, induction of TGF- $\beta$ and modulation of TGF- $\beta$ induction by both JP4-039 and MMS350, were observed. The data suggest that the agents, which reduce irradiation or chemotherapy-induced TGF- $\beta$ might be of value in marrow transplant regimen and facilitate better engraftment while reducing toxicity.

\section{Materials and Methods}

Mice and animal care. Control 129/Sv, SMAD3--- (129/Sv), control C57BL/6NTac (34), FANCD2-I- (B6) (15), and Double Knockout (DKO) SMAD3 ${ }^{--}(129 / \mathrm{Sv})$ FANCD2 ${ }^{-/-}$(C57BL/6) mice (35) were housed, 5 animals per cage, at the University of Pittsburgh Cancer Institute according to the University of Pittsburgh Institutional Animal Care and Use Committee (IACUC) protocols. Heterozygote TGF- $\beta^{+/-}$mice (C57BL/6 background) were obtained from Jackson Laboratories (Bar Harbor, ME, USA). Mice were bred to produce TGF- $\beta^{-/-}$mice. Marrow was removed from TGF- $\beta^{-/-}$mice on the day of birth to establish bone marrow stromal cell lines. All protocols were approved by the University of Pittsburgh IACUC. Animals were fed standard laboratory chow and deionized water.

Bone marrow culture. Fresh bone marrow was explanted from the mouse femur and tibia at serial time points after administration of chemotherapy drugs and plated in 6 -well culture plates at $5 \times 10^{4}$ cells/per well for hematopoietic colony assays according to published methods (34). The medium was supplemented with hematopoietic growth factors as described (29) to stimulate multilineage hematopoietic stem cell growth. Colonies of greater than 50 cells were scored at days 7 and 14 (34).

Chemotherapeutic drugs tested were L-Phenylalanine Mustard (L-PAM), Busulfan, and Fludarabine (Sigma-Aldrich Chemical Company, St. Louis, MO, USA). Each drug was added to bone marrow cultures or injected intravenously into mice using established manufacturer's procedures.

Total body irradiation. Mice were irradiated using a Gammacell Mark IV Cesium-137 gamma cell irradiator at $70 \mathrm{cGy} /$ minute to the lethal dose of $10 \mathrm{~Gy}$ (29). Bone marrow was removed from mice at several time points after irradiation and TGF- $\beta$ levels as well as other biomarkers of the irradiation response were analyzed. Plasma was withdrawn from the cardiac puncture of mice at serial time points after total body irradiation and assayed for TGF- $\beta$, as well as other inflammatory cytokines according to established methods (29).

TGF- $\beta$ assays. Cell conditioned medium, cell lysates, and mouse plasma were tested for TGF- $\beta$ using TGFBMAG-64K-01 Milliplex Map TGF- $\beta$ Signaling Pathway Magnetic Bead 6-Plex-Cell Signaling Multiples Assay (EMD Millipore, Billerica, MA, USA) according to published methods. For plasma studies, blood was isolated form the mice by cardiac puncture and placed in EDTA collection tubes, centrifuged for $10 \mathrm{~min}$ at $1,000 \mathrm{rpm}$ and plasma removed. Plasma was diluted 1:4 with sample diluent from Milliplex kit and $2.0 \mu \mathrm{l}$ of $1.0 \mathrm{~N} \mathrm{HCI}$ per $50 \mu \mathrm{l}$ of diluted sample was added and shaken for $15 \mathrm{~min}$ at room temperature. The acidtreated samples were diluted 1:6 using Assay Buffer. To the appropriate wells, standard or sample $(25 \mu \mathrm{l}), 25 \mu \mathrm{l}$ of matrix solution, and $25 \mu \mathrm{l}$ of mixed beads was added. The plates were sealed with a plate sealer, and shaken for $2 \mathrm{~h}$ at room temperature or overnight at $4{ }^{\circ} \mathrm{C}$. Well contents were removed, washed twice with $200 \mu \mathrm{l}$ of Wash Buffer, added $25 \mu \mathrm{l}$ of detection antibodies to each well, incubated for one hour at room temperature and added $25 \mu \mathrm{l}$ of streptavidin-Phycoerythrin per well. These plates were then incubated for $30 \mathrm{~min}$ at room temperature and washed twice with $200 \mu \mathrm{l}$ of Wash Buffer. Finally, $100 \mu \mathrm{l}$ of Sheath Fluid per well was added and results were read on the Luminex Reader. TGF- $\beta$ levels were recorded as $\mathrm{ng} / \mathrm{ml}$.

Cell lines. Bone marrow stromal cell lines (34) and IL-3 dependent hematopoietic progenitor cell lines $(34,36)$ were established from control C57BL/6NTac, FANCD2-/- and FANCD2+/- (B6) long-term bone marrow cultures according to published methods (34). Bone marrow stromal cell lines were established from TGF- $\beta^{-/-}$newborn mice on day one after birth according to published methods (34), or from the adherent layer of four week old long-term bone marrow cultures from $T G F-\beta^{+/-}$and $T G F-\beta^{+/+}$control (C57BL/6NTac) mice according to published methods (31). Clonal sublines used were designated $T G F-\beta^{+/+} 2 \mathrm{~A} 6, T G F-\beta^{+/-} 2 \mathrm{C} 9$, and $T G F-\beta^{-/-} 2 \mathrm{C} 7$. Bone marrow stromal cell lines were passaged weekly in Dulbecco's modified Eagle's medium supplemented with $15 \%$ fetal bovine serum.

IL-3 dependent cell lines derived from long term bone marrow cultures that were established from $F A N C D 2^{-/-}$and $F A N C D 2^{+/+}$ mice have been previously reported (34). Each cell line was passaged in suspension culture in IL-3 supplemented medium according to published methods $(34,36)$. For TGF- $\beta$ assays, all cell lines were transferred to serum free medium, left unirradiated as controls or irradiated to $10 \mathrm{~Gy}$ or drug treated. Medium was collected $24 \mathrm{~h}$ after irradiation or drug treatment. Cell lysates were obtained and TGF- $\beta$ levels were assayed by Luminex assay as described above.

Western blots. Cell lines were cultured in DMEM medium (Lonza, Cat. \#12-604F, Allendale, NJ, USA) with 10\% Fetal Bovine serum (Gemini, Cat. \#: 100-500, West Sacramento, CA, USA), 1\% LGlutamine (Lonza Cat. \#17-605E), and 1\% Antibiotics Antimycotic Solution (Corning, Cat. \#30-004-C1, Sigma-Aldrich, St. Louis, MO, USA). Total cellular protein was extracted using protein extraction buffer (IP Lysis Buffer, Thermo Scientific, Cat. \#87787, Waltham, MA, USA), containing protease inhibitor and phosphatase inhibitor cocktails (Thermo Scientific, Cat. \#78442). Protein concentration was determined using the Bio-Rad protein assay system (Bio-Rad Laboratories, Cat. \#500-0006, Hercules, CA, USA). The proteins (15 $\mu \mathrm{g}$ per lane) were separated on denaturing polyacrylamide gels (Bio-Rad Laboratories, Mini-Protein TGX Gels Cat \#: 456-1083) and then transferred to PVDF membranes (Bio-Rad Laboratories, Immun-Blot PVDF, Cat. \#162-0177) by electrophoresis. Blots were blocked with 5\% Fat-free dry milk in TBST for $1 \mathrm{~h}$ and then incubated overnight with primary antibodies against p-ERK, p-S6K, p-SMAD3, p-JNK, p21, and RAD51. Membranes were washed with 
Table I. Induction of TGF- $\beta$ in vitro with explanted marrow from FANCD2--- $(C 57 B L / 6)$ and control male mice and in plasma removed from 10 Gy TBI, L-PAM, Bulsulfan, or Fludarabine treated mice. (Reprinted from: Fanconi Anemia (FA): Genetic Prevalence, Management, and Treatment Outcomes, "Radiotherapy for the patient with Fanconi Anemia: A challenge for the radiation oncologist", 2015, Greenberger, Joel S and Epperly, Michael W with permission from Nova Science Publishers, Inc.)

\begin{tabular}{|c|c|c|c|c|c|c|c|c|}
\hline \multirow[t]{3}{*}{ Condition } & \multicolumn{4}{|c|}{ In Vitro } & \multicolumn{4}{|c|}{ In Vivo } \\
\hline & \multicolumn{2}{|c|}{$F A N C D 2^{+/+}$} & \multicolumn{2}{|c|}{ FANCD $2^{-/-}$} & \multicolumn{2}{|c|}{$F A N C D 2^{+/+}$} & \multicolumn{2}{|c|}{ FANCD $2^{-/-}$} \\
\hline & $\begin{array}{l}\text { TGF- } \beta \\
(\mathrm{pg} / \mathrm{ml})\end{array}$ & $\begin{array}{c}\text { Fold } \\
\text { increase }\end{array}$ & $\begin{array}{l}\text { TGF- } \beta \\
(\mathrm{pg} / \mathrm{ml})\end{array}$ & $\begin{array}{c}\text { Fold } \\
\text { increase }\end{array}$ & $\begin{array}{l}\text { TGF- } \beta \\
(\mathrm{pg} / \mathrm{ml})\end{array}$ & $\begin{array}{c}\text { Fold } \\
\text { increase }\end{array}$ & $\begin{array}{l}\text { TGF- } \beta \\
(\mathrm{pg} / \mathrm{ml})\end{array}$ & $\begin{array}{l}\text { Fold } \\
\text { increase }\end{array}$ \\
\hline 0 Gy & $820 \pm 159$ & & $1057 \pm 9$ & & $2474 \pm 43$ & & $1197 \pm 56$ & \\
\hline $10 \mathrm{~Gy}$ & $961 \pm 105$ & $1.2 \pm 0.2$ & $1556 \pm 216$ & $1.1 \pm 0.1$ & $\begin{array}{c}2742 \pm 54 \\
\mathrm{P} 2=0.0186\end{array}$ & $1.1 \pm 0.1$ & $\begin{array}{c}1561 \pm 42 \\
\mathrm{P} 2=0.0067\end{array}$ & 1.30 .2 \\
\hline $\begin{array}{l}10 \mathrm{~Gy}+ \\
\text { JP4-039 }\end{array}$ & $\begin{array}{c}230 \pm 115 \\
\mathrm{P} 1=0.0152\end{array}$ & $0.3 \pm 0.1$ & $\begin{array}{c}295 \pm 35 \\
\mathrm{P} 1=0.0484\end{array}$ & $0.3 \pm 0.1$ & & & & \\
\hline $\begin{array}{l}10 \mathrm{~Gy}+ \\
\text { MMS350 }\end{array}$ & $\begin{array}{c}435 \pm 45 \\
\mathrm{P} 1=0.0222\end{array}$ & $0.5 \pm 0.1$ & $\begin{array}{c}367 \pm 52 \\
\mathrm{P} 1=0.0435\end{array}$ & $0.4 \pm 0.1$ & & & & \\
\hline L-PAM & $5395 \pm 161$ & $6.6 \pm 0.4$ & $2325 \pm 465$ & $2.2 \pm 0.2$ & $2022 \pm 61$ & $0.9 \pm 0.1$ & $\begin{array}{l}2623 \pm 115 \\
\mathrm{P} 2=0.0004\end{array}$ & $2.2 \pm 0.2$ \\
\hline $\begin{array}{l}\text { L-PAM + } \\
\text { JP4-309 }\end{array}$ & $\begin{array}{c}3116 \pm 324 \\
\mathrm{P} 1=0.0048\end{array}$ & $3.8 \pm 0.3$ & $2790 \pm 1116$ & $1.2 \pm 0.5$ & & & & \\
\hline $\begin{array}{l}\text { L-PAM + } \\
\text { MMS350 }\end{array}$ & $3690 \pm 1230$ & $4.5 \pm 0.8$ & $1321 \pm 330$ & $1.3 \pm 0.4$ & & & & \\
\hline Bulsulfan & $2271 \pm 45$ & $2.8 \pm 0.1$ & $1511 \pm 377$ & $1.4 \pm 0.3$ & $\begin{array}{c}1512 \pm 47 \\
\mathrm{P} 2=0.0001\end{array}$ & $0.6 \pm 0.1$ & $1140 \pm 115$ & $0.9 \pm 0.1$ \\
\hline $\begin{array}{l}\text { Bulsulfan + } \\
\text { JP4-039 }\end{array}$ & $2378 \pm 71$ & $2.9 \pm 0.3$ & $\begin{array}{c}528 \pm 176 \\
\mathrm{P} 1=0.0205\end{array}$ & $0.5 \pm 0.1$ & & & & \\
\hline $\begin{array}{l}\text { Bulsulfan + } \\
\text { MMS350 }\end{array}$ & $3165 \pm 633$ & $3.9 \pm 0.6$ & $\begin{array}{c}422 \pm 84 \\
\mathrm{P} 1=0.0214\end{array}$ & $0.4 \pm 0.1$ & & & & \\
\hline Fludarabine & $1435 \pm 358$ & $1.7 \pm 0.3$ & $2642 \pm 1321$ & $2.5 \pm 0.5$ & $\begin{array}{c}1994 \pm 82 \\
\mathrm{P} 2=0.0061\end{array}$ & $0.8 \pm 0.1$ & $1355 \pm 74$ & $1.1 \pm 0.1$ \\
\hline $\begin{array}{l}\text { Fludarabine + } \\
\text { JP4-039 }\end{array}$ & $1025 \pm 256$ & $1.3 \pm 0.3$ & $1717 \pm 214$ & $1.6 \pm 0.1$ & & & & \\
\hline $\begin{array}{l}\text { Fludarabine + } \\
\text { MMS350 }\end{array}$ & $1127 \pm 141$ & $1.4 \pm 0.1$ & $1453 \pm 182$ & $1.4 \pm 0.1$ & & & & \\
\hline
\end{tabular}

Drugs and irradiation were delivered to freshly explanted whole marrow (triplicate experiments) in culture, and medium collected for analysis of TGF$\beta$. TBI or drugs were delivered to mice ( $\mathrm{n}=10$ /group) for collection of plasma $24 \mathrm{~h}$ later, as described in the methods, and plasma was assayed for TGF$\beta$ levels. P1 is comparison of treatment groups treated with JP4-039, or MMS350 to treatment groups only (50 $\mu$ M L-PAM, $100 \mu \mathrm{M}$ Bulsulfan, or 2 $\mu \mathrm{M}$ Fludarabine. P2 is comparison of TGF- $\beta$ level in plasma from $F A N C D 2^{+/+}$or $F A N C D 2^{-/-}$mice to TGF- $\beta$ level in plasma from $F A N C D 2^{+/+}$or FANCD $2^{-/}$-mice treated with $10 \mathrm{~Gy}$, L-PAM $(15 \mathrm{mg} / \mathrm{kg})$, Busulfan $(30 \mathrm{mg} / \mathrm{kg})$ or Fludarabine $(30 \mathrm{mg} / \mathrm{kg})$.

TBST and processed with corresponding horseradish peroxidaseconjugated secondary antibodies. The proteins were exposed to $\mathrm{x}$ ray film (5 to $30 \mathrm{sec}$ ) using ECL detection reagent (Thermo Scientific SuperSignal West Dura Extended Duration Substrate, Cat. \#34075). To ensure equal protein loading, the same blot was subsequently developed for $\beta$-actin expression.

Chemotherapeutic drugs and radiation mitigator small molecules. L-Phenylalanine Mustard (L-PAM), Busulfan, and Fludarabine were obtained from the supplier (Sigma-Aldrich, St. Louis, MO, USA). For in vitro experiments, L-PAM was used at $50 \mu \mathrm{M}$, Busulfan at $100 \mu \mathrm{m}$, and fludarabine at $2 \mu \mathrm{M}$, while for in vivo studies, L-PAM was used at $15 \mathrm{mg} / \mathrm{kg}$, busulfan at $30 \mathrm{mg} / \mathrm{kg}$, and fludarabine at $30 \mathrm{mg} / \mathrm{kg}$. The TGF- $\beta$ receptor antagonist drug LY36937 was obtained from the supplier (Selleckchem.com, Houston, TX, USA). Drug was added to cultures at $5 \mu \mathrm{M}$. The radiation mitigator drug JP4-039 (30) and MMS350 (32) have been described.
Statistical analysis. Data was assayed by Student's modified $t$-test, and significance was determined for differences with $p$-value less than 0.05 .

\section{Results}

FANCD2 $2^{-/}$Mouse bone marrow stromal cell lines and IL-3dependent hematopoietic progenitor cell lines produce TGF- $\beta$ in vitro. TGF- $\beta$ was secreted by control as well as, $10 \mathrm{~Gy}$ irradiated $F A N C D 2^{+/+}$and $F A N C D 2^{-/-}$bone marrow stromal cell lines and IL-3 dependent hematopoietic progenitor cell lines (Table I and Figure 1). TGF- $\beta$ was also detected in the cellular lysates of $F A N C D 2^{+/+}$and FANCD2 $2^{-/-}$cell lines (Figure 2). Levels were decreased in lysates from irradiated marrow stroma cells (Figure 2A). TGF- $\beta$ was also detected in medium from 


\section{A}

\section{FANCD2 Marrow Stromal Cell Line Medium}

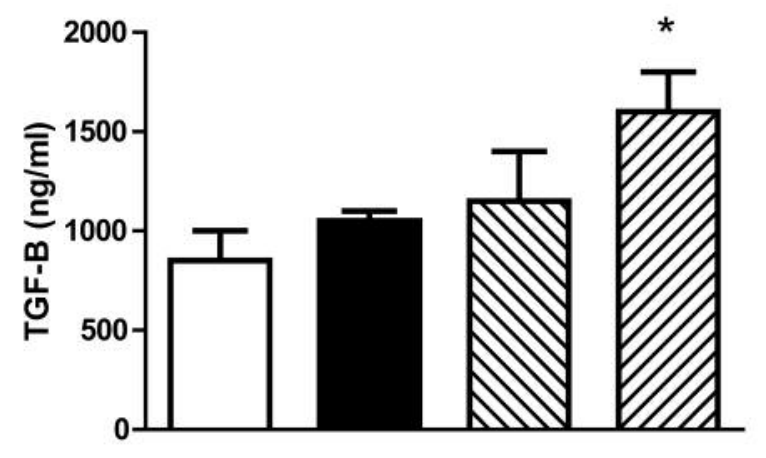

${ }^{*} p<0.05$ compared to $0 \mathrm{~Gy}$

B
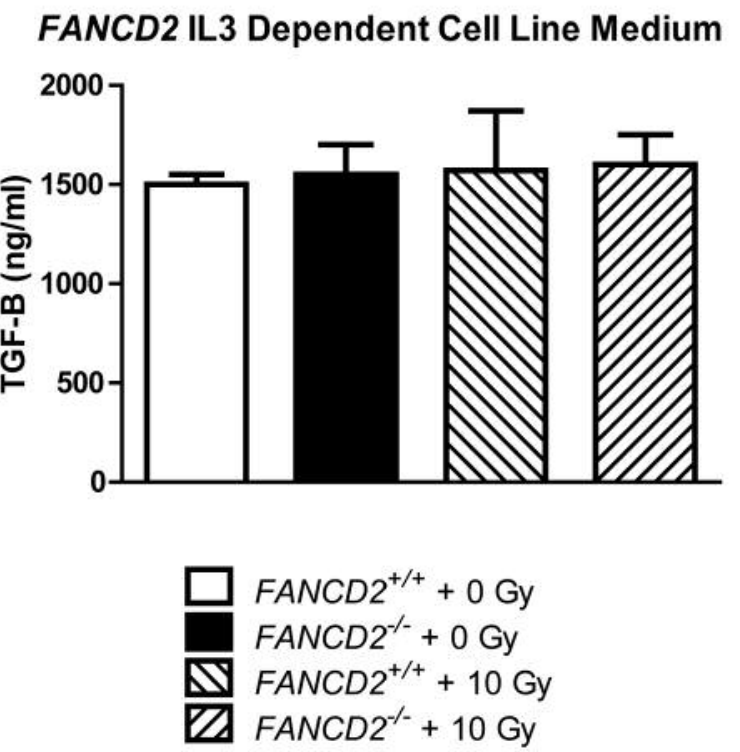

Figure 1. Quantitation of levels of TGF- $\beta$ in culture medium from $10 \mathrm{~Gy}$ irradiated or control FANCD2-/- and FANCD2 $2^{+/+}$marrow stromal cell lines and IL-3 dependent hematopoietic progenitor cell lines. Serum free tissue culture medium was harvested at $24 \mathrm{~h}$ after treatment from bone marrow stromal (A) and IL-3 dependent cell lines (B) and tested by Luminex analysis for TGF- $\beta$ production as described in the methods.

control F1 (129/Sv x C57BL/6), as well as $S M A D 3^{-/-}(129 / \mathrm{Sv})$, FANCD2 $2^{-/}(\mathrm{C} 57 \mathrm{BL} / 6)$ and double-knockout SMAD3 $^{-/-}$ $(129 / \mathrm{Sv}) / F_{A N C D 2^{-/}}$(B6) mouse marrow stromal cell lines. SMAD3 $^{-/-}(129 / \mathrm{Sv})$ mice are known to be defective in TGF- $\beta$ signaling (20-22). The results confirm and extend prior publications showing TGF- $\beta$ production with $\mathrm{SMAD}^{-/-}$bone marrow stromal cell lines (which have a defective canonical TGF- $\beta$ signal transduction pathway (22)), and the data include
A

FANCD2 Marrow Stromal Cell Lysate

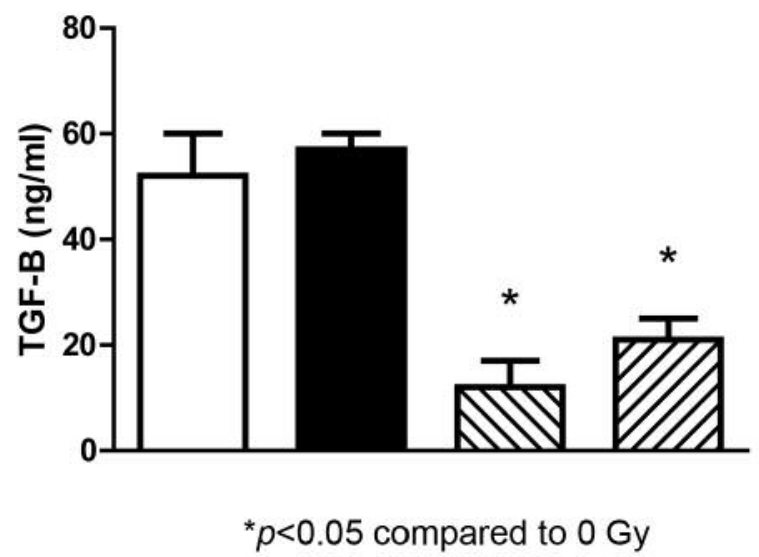

B

FANCD2 IL3 Dependent Cell Line Lysates
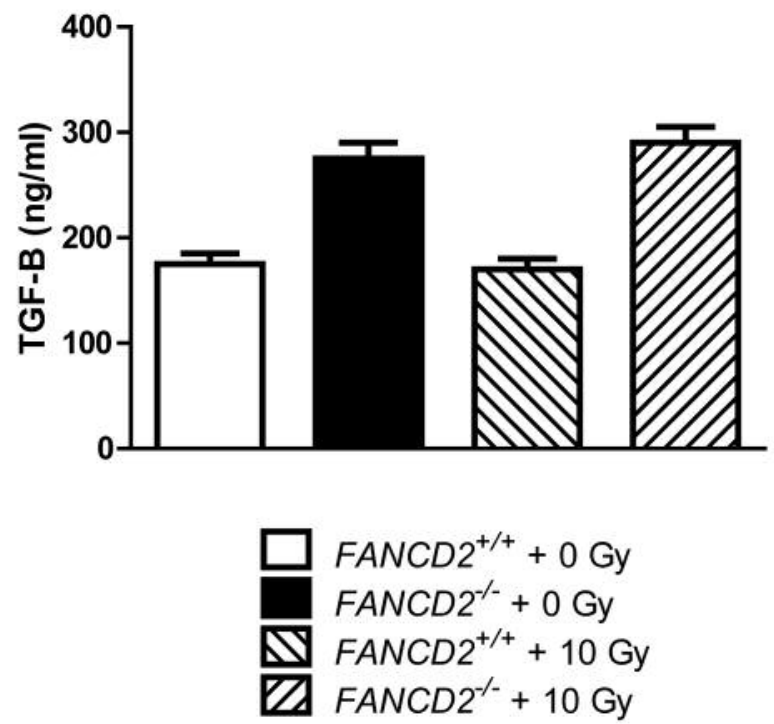

Figure 2. Quantitation of levels of TGF- $\beta$ in cell lysates from 10-Gy irradiation or control FANCD2 $2^{-/}$or FANCD2 $2^{+/+}$marrow stromal cell lines and IL-3 dependent cell lines. Cell lysates were prepared from bone marrow stromal cells (A) and IL-3-dependent cells $(B)$ and tested by Luminex analysis for the production of TGF- $\beta$, as described in the methods.

a negative control bone marrow cell line from $T G F-\beta^{-/-}$mice. There was no detectable TGF- $\beta$ secreted by $T G F-\beta^{-/-}$stromal cell lines (data not shown).

All five of the known signaling pathways for TGF- $\beta$ (37) were intact in $T G F-\beta^{-/}$as well as the other cell lines tested (Figure 3 ). The canonical TGF- $\beta$ signaling pathway was intact in all cell lines $\left(T G F-\beta^{-/-}, T G F-\beta^{+/-}\right.$, and $\left.T G F-\beta^{+/+}\right)$, as shown by phosphorylated p-SMAD3 (Figure 3 ). The ERK 

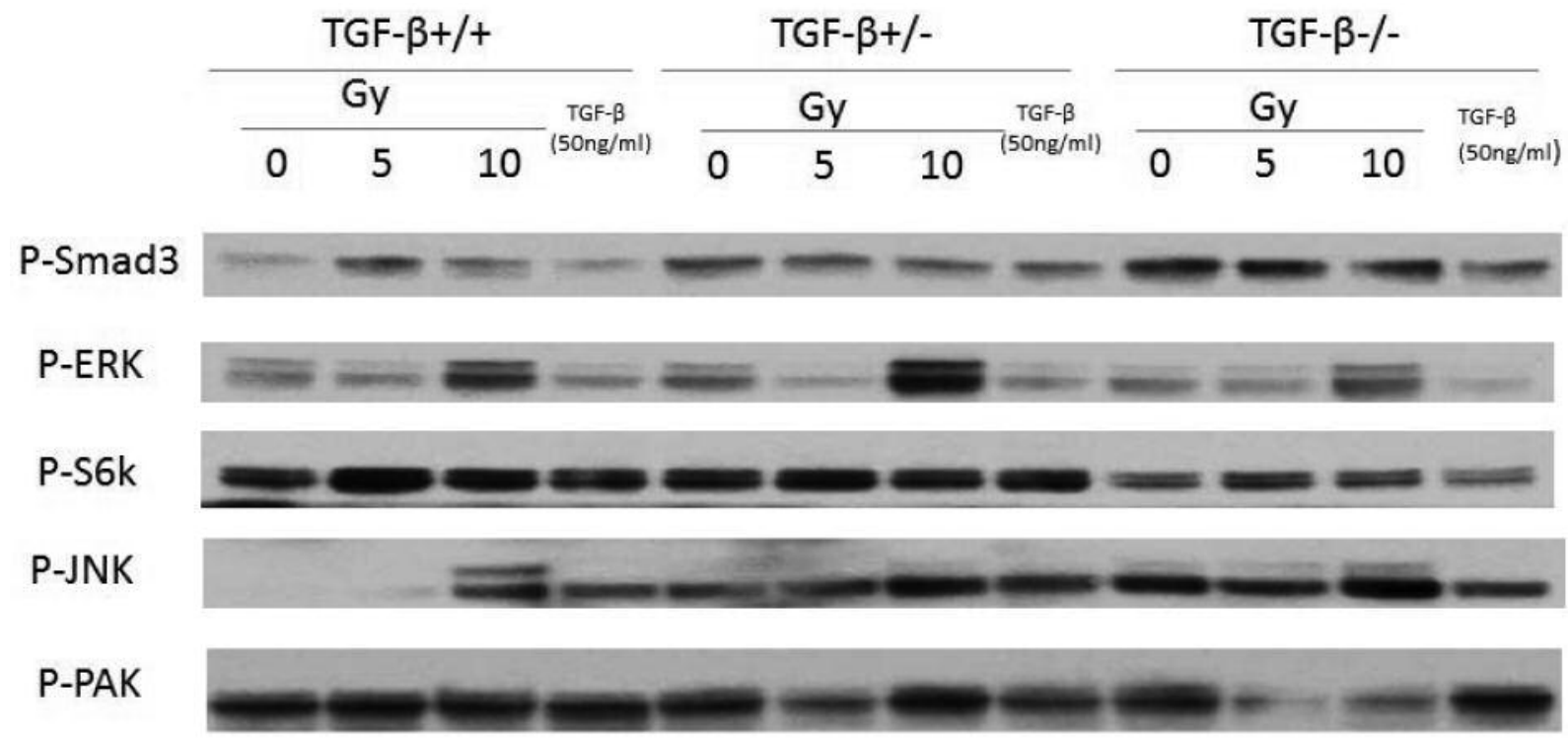

P21

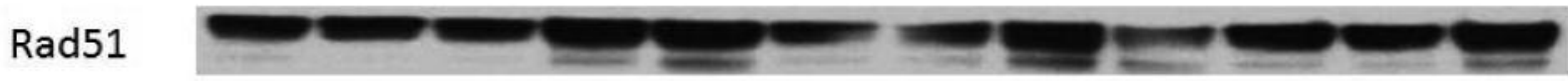

$\beta$ - actin

Figure 3. Western blot analysis of each of five TGF- $\beta$ signaling pathways in bone marrow stromal cell lines from TGF- $\beta^{-1-}$ and control mice. TGF$\beta^{+/+}$(B6) TGF- $\beta^{+/-}$, and TGF- $\beta^{-/-}$mouse bone marrow stromal cell lines were tested as described in the methods for protein phosphorylation markers of each of the SMAD-dependent and non-SMAD-dependent TGF- $\beta$ signaling pathway (37).

non-SMAD pathway was intact, as shown by $\mathrm{p}$-ERK. The $\mathrm{JNK} / \mathrm{p} 38$ pathway was intact, as shown by $\mathrm{p}-\mathrm{JNK}$. Here the $T G F-\beta^{+/+}$cell line showed increases in p-JNK after $10 \mathrm{~Gy}$ or addition of $50 \mathrm{mg} / \mathrm{ml}$ TGF- $\beta$. The small GTP.ase (Rholike) non-SMAD pathway was intact shown by p-PAK. The $\mathrm{p} 13 \mathrm{~K} /$ Akt non-SMAD pathway was intact as shown by $\mathrm{p}$ S6K (Figure 3). Levels of p21 were more inducible by TGF$\beta$ or radiation in TGF- $\beta^{-/-}$cells.

We tested $T G F-\beta^{-/}$cell lines for clonogenic radiation survival in vitro. TGF $-\beta^{-/-}$and $T G F-\beta^{+/-}$cell lines were radiosensitive relative to control TGF- $\beta^{+/+}$(B6) cells (Figure 4 and Table II).

The data establish that TGF- $\beta$ was produced by both bone marrow stromal and IL-3 dependent cell lines (Figures 1 and 2) derived from long-term marrow cultures of FANCD2 $2^{-/-}$ mouse marrow (34). The data establish that TGF- $\beta$ was both accumulated intracellularly, and secreted. Bone marrow stromal cells represent the phenotype of a major component of the hematopoietic microenvironment of recipient bone marrow transplantation. The results also establish that ionizing irradiation induces TGF- $\beta$ in FANCD2 $2^{-1-}$ mouse bone marrow stromal cells in vitro (Figure 1A).
Table II. Analysis of radiosensitivity by clonogenic survival curves of $T G F-\beta^{+/+}, T G F-\beta^{+/-}$, and TGF- $\beta^{-/-}$bone marrow stromal cell lines.

\begin{tabular}{lccc}
\hline Cell Line & Cloning efficiency $(\%)$ & Do (Gy) & $\check{\mathrm{n}}$ \\
\hline$T G F-\beta^{+/+} 2 \mathrm{~A} 6$ & $0.20 \pm 0.01$ & $1.95 \pm 0.03$ & $5.2 \pm 1.3$ \\
$T G F-\beta^{+/-}$C 9 & $0.13 \pm 0.06$ & $1.33 \pm 0.03$ & $18.0 \pm 3.6$ \\
& & $(p=0.0003)$ & \\
$T G F-\beta^{-/-} 2 \mathrm{C} 7$ & $0.05 \pm 0.01$ & $1.31 \pm 0.14$ & $6.0 \pm 2.9$ \\
& & $(p=0.0409)$ & \\
\hline
\end{tabular}

Radiation survival curves were carried out in triplicate, as described in the methods. Full curves are shown in Figure 4. $p$-Values were generating by comparing Do with $T G F-B^{+/+}$cell lines.

Ionizing irradiation and chemotherapeutic drugs induce TGF$\beta$ in FANCD2 $2^{-/}$mouse cell lines. We tested the effect of irradiation, L-phenylalanine mustard (L-PAM), busulfan, and fludarabine on TGF- $\beta$ induction in bone marrow stromal cells in vitro and in IL-3-dependent hematopoietic cells. We compared TGF- $\beta$ induction levels from $F A N C D 2^{-/-}$cells with 


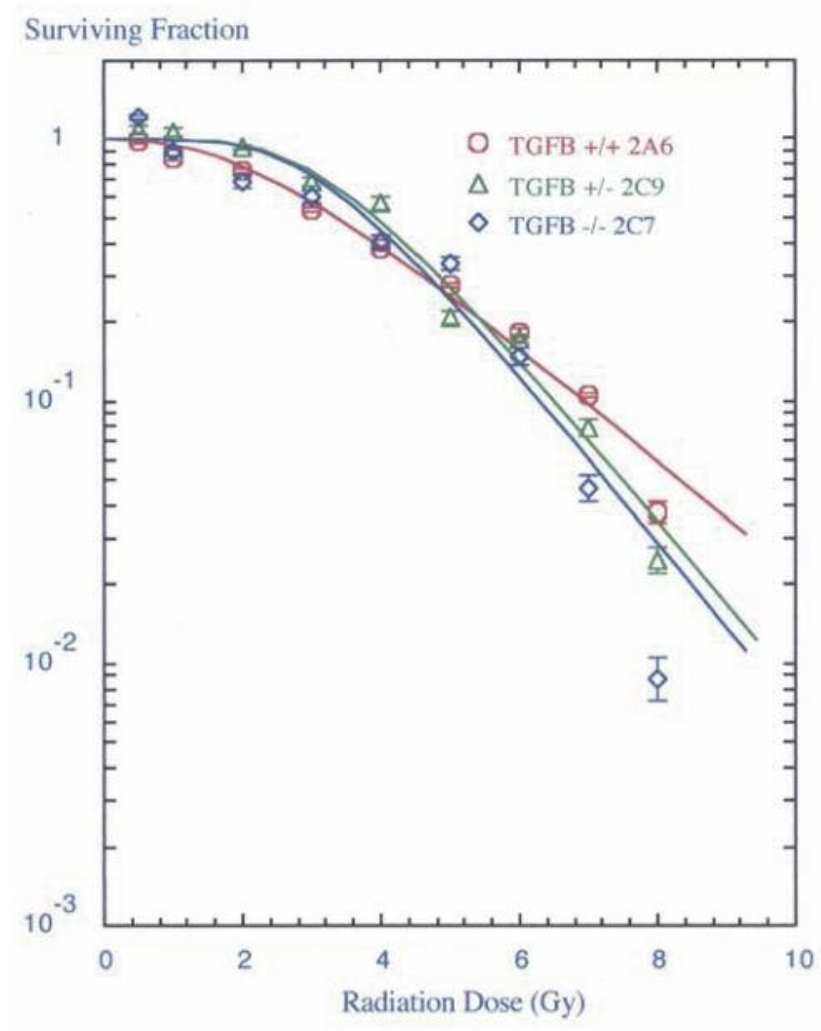

Figure 4. Clonogenic radiation survival curves of TGF- $\beta^{-/-}, T G F-\beta^{+/}$, and $T G F-\beta^{+/+}$bone marrow stromal cell lines. Each stromal cell line from $T G F-\beta^{-/-}, T G F-\beta^{+/-}$, and $T G F-\beta^{+/+}$mouse marrow was analyzed for radiation survival. Cells were irradiated to doses of 0-8 Gy and plated in tissue culture plates as published (34). Colonies of $\geq 50$ cells were scored at day 7, as described in the methods (results were generated in triplicate experiments).

those from control wild-type C57BL/6J cells. The results are shown in (Figure 5, Table I). Each drug, as well as irradiation, demonstrated significant induction of TGF- $\beta$ levels in vitro (Table I, Figure 5). While the magnitude of induction by each agent varied, there was a uniform increase in levels of TGF- $\beta$ in FANCD $2^{-/-}$compared to wild-type C57BL/6NTac mouse bone marrow cells tested in vitro (Figure 5, Table I).

These data establish that TGF- $\beta$ was released into serumfree medium of bone marrow cultures of each stromal cell line including, both $F A N C D 2^{-/-}$and wild-type bone marrow stromal cell lines, and was induced by each marrow transplant preparatory agent.

Total-body irradiation and chemotherapy drugs induce TGF$\beta$ in vivo. We evaluated plasma levels of TGF- $\beta$ in total body irradiated or chemotherapy treated mice. As shown in Table 1 levels of TGF- $\beta$ in vivo were significantly elevated by treatment with each bone marrow transplant preparatory regimen. The levels of TGF- $\beta$ were significantly elevated by irradiation or drug treatment in both $F A N C D 2^{-/-}$and control background strain C57BL/6NTac mice, and there was no significant difference between the mouse genotypes in the levels measured at the indicated time point (Table I).

Radiation mitigator drugs suppress induction of TGF- $\beta$. The radiation mitigator drugs JP4-039 (30) and MMS350 (32) were each tested for mechanism of action in vitro, specifically for effects of 5-Gy irradiation on autophagy compared to apoptosis in vitro using 32D cl 3 cells (36). In vitro JP4-039 was dissolved in DMSO (26), and MMS350 (32) dissolved in water. Each drug had effects on radiation suppressed autophagy and radiation induced apoptosis (Figure 6). Irradiation suppressed autophagy in vitro and the suppression was corrected by each drug delivered before or after irradiation (Figure 6). JP4-039 and MMS350 each reduced levels of TGF- $\beta$ that was induced in vitro in FANCD $2^{-/-}$and control mouse cell lines treated with $10-\mathrm{Gy}$ irradiation (Figure 5A), L-PAM (melphalan) (Figure 5B), busulfan (with the exception of the MMS350 effect on Fancd $2^{+/+}$cells) (Figure 5C) and fludarabine (Figure 5D).

The small molecule inhibitor of TGF- $\beta$ signaling (LY364947) ameliorates the TGF- $\beta$ growth-suppression of fresh marrow colony forming cells. We tested the effect of a small molecule TGF- $\beta$ signal transduction inhibitor (LY364947 delivered at $5 \mu \mathrm{M})$ on freshly-explanted bone marrow hematopoietic cell colony formation cells. Freshly explanted marrow cells from FANCD $2^{-/-}$or FANCD2 $2^{+/+}$mice were treated with $50 \mathrm{ng} / \mathrm{ml}$ TGF- $\beta$ or received 5-Gy irradiation. Subgroups received $5 \mu \mathrm{M}$ LY364947. As shown in Figure 7, small molecule TGF- $\beta$ inhibitor LY364947 delivered alone increased colony formation by both $F A N C D 2^{-/-}$and $F A N C D 2^{+/+}$bone marrow cells. The drug also increased colony growth in both genotypes cell treated with TGF- $\beta$. FANCD2 $2^{+/+}$marrow irradiated to $5 \mathrm{~Gy}$ also shows stimulation of colony formation by LY364947. The dose of 5 Gy was toxic to FANCD2 $2^{-/-}$marrow such that LY364947 showed no detectable stimulation of recovery.

\section{Discussion}

Bone marrow transplantation is a standard treatment option for FA patients, as well as other patients with genetic or acquired failure of hematopoiesis (1-4). Fanconi Anemia patients now show significant improvement in survival and quality of life by addition of bone marrow transplantation to their therapeutic regimen (14-15). The success of bone marrow transplantation includes preparation of the recipient for engraftment of donor bone marrow stem cells. Donor hematopoietic stem cells home to the recipient microenvironment niche in vivo, where they return to quiescence, and are called upon by competing proliferative demands to display self-renewal or differentiation to multiple lymphopoietic and hematopoietic cell lineages (17). 

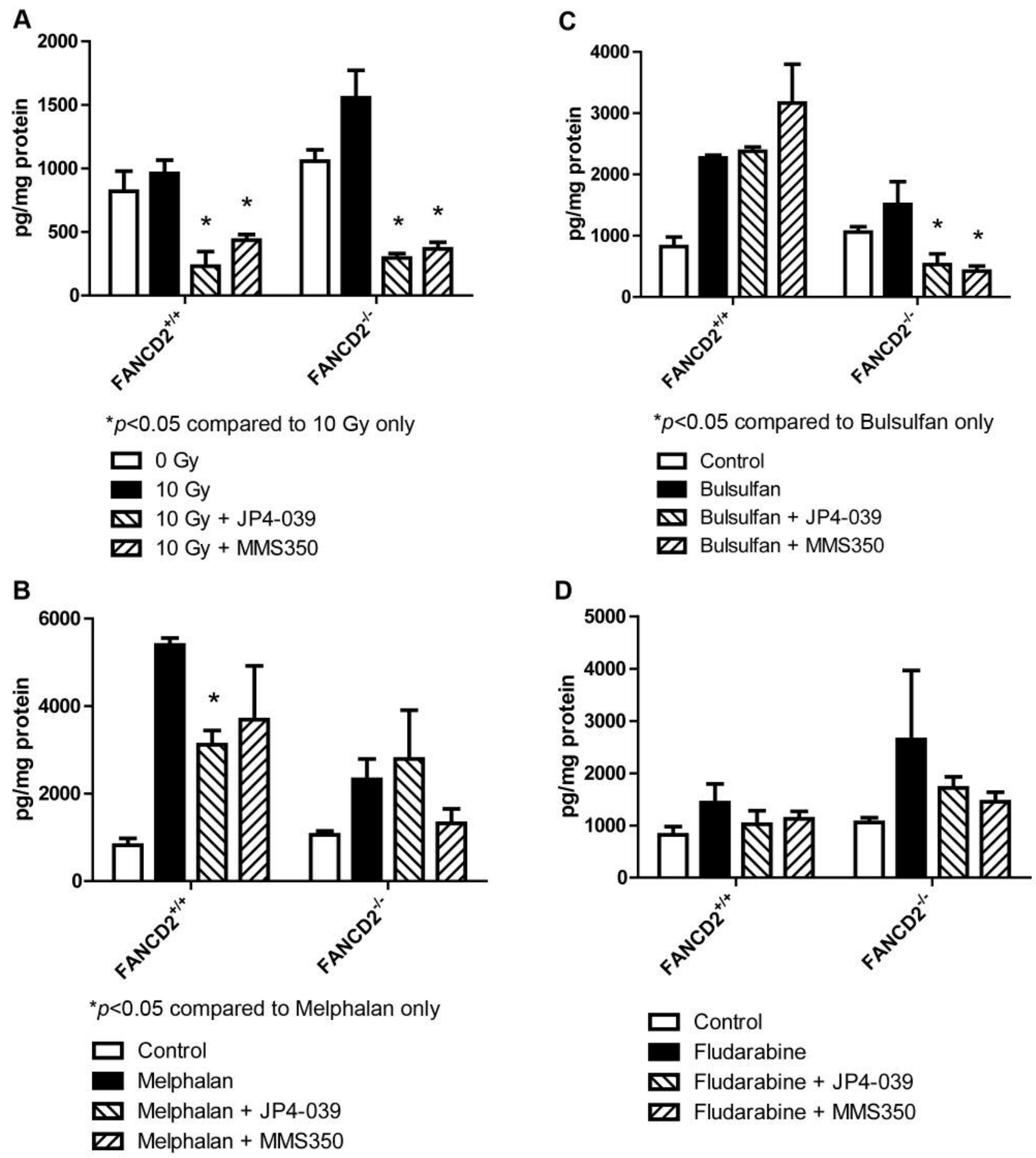

${ }^{*} p<0.05$ compared to Bulsulfan only

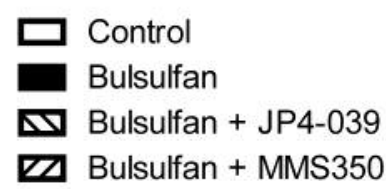

B

Figure 5. Effect of JP4-039 $(10 \mu M)$ or MMS350 $(100 \mu M)$ on TGF- $\beta$ levels in FANCD2+/+ and FANCD2-/- bone marrow stromal cells. (A) 10-Gy irradiation; (B) melphalan (L-phenylalanine mustard) $(50 \mu M)$; (C) busulfan $(100 \mu M)$, or (D) fludarabine $(2 \mu M)$. Medium was harvested 24 hrs later and assayed for TGF- $\beta$ using Luminex assay (triplicate experiments).

Central to successful marrow stem cell engraftment is clearing the recipient bone marrow niche for donor stem cell transplantation. Preparation of the transplant recipient has included the use of total body irradiation and/or cytotoxic chemotherapeutic agents including: L-Phenylalanine Mustard (L-PAM or Melphalan), Busulfan, and Fludarabine (24-25). 


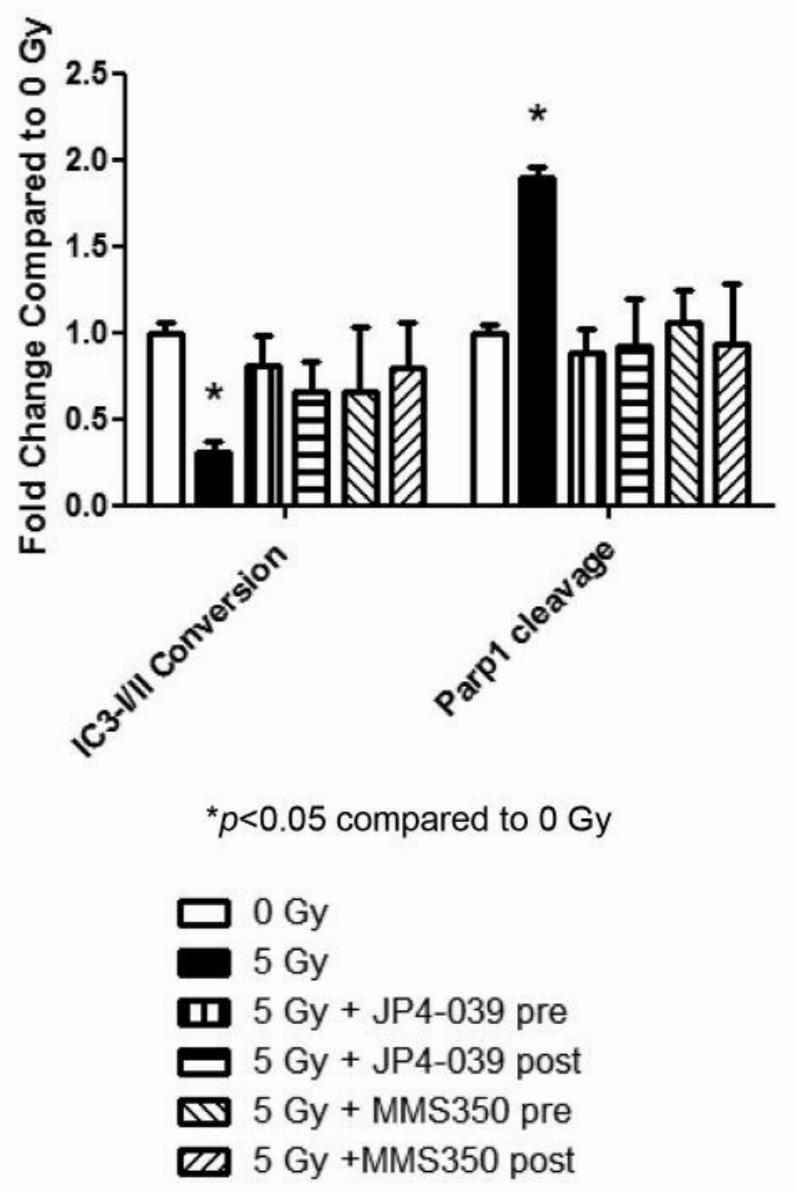

Figure 6. Mechanism of action of JP4-039 and MMS350. Assays for autophagy (40) and apoptosis (36) were carried out with JP4-039 or MMS350 treated cells using 5 Gy irradiated or control non-irradiated $32 \mathrm{D} \mathrm{cl} 3$ cells. Cells from triplicate experiments were treated with each drug 10 min before or immediately after 5-Gy irradiation and tested in each assay. Medium was changed to serum free medium and cell cultures treated with cytotoxic agents.

Total body irradiation (TBI), or subtotal body irradiation is still used to facilitate engraftment (6).

The irradiated or drug treated recipient marrow niche produces negative regulators of hematopoiesis including TGF- $\beta(16,19-22)$. A hyperactive TGF- $\beta$ response pathway has recently been demonstrated in both FA patients and in animal models of FA (5). The data have suggested the potential value of utilizing a TGF- $\beta$ signal transduction inhibitor as a therapeutic agent to improve marrow stem cell engraftment in FA patients.

We tested the hypothesis that TGF- $\beta$ was elevated in FA marrow following application of the agents used in the preparative regimen for transplant. We found that chemotherapy drugs L-PAM, busulfan, and fludarabine, and
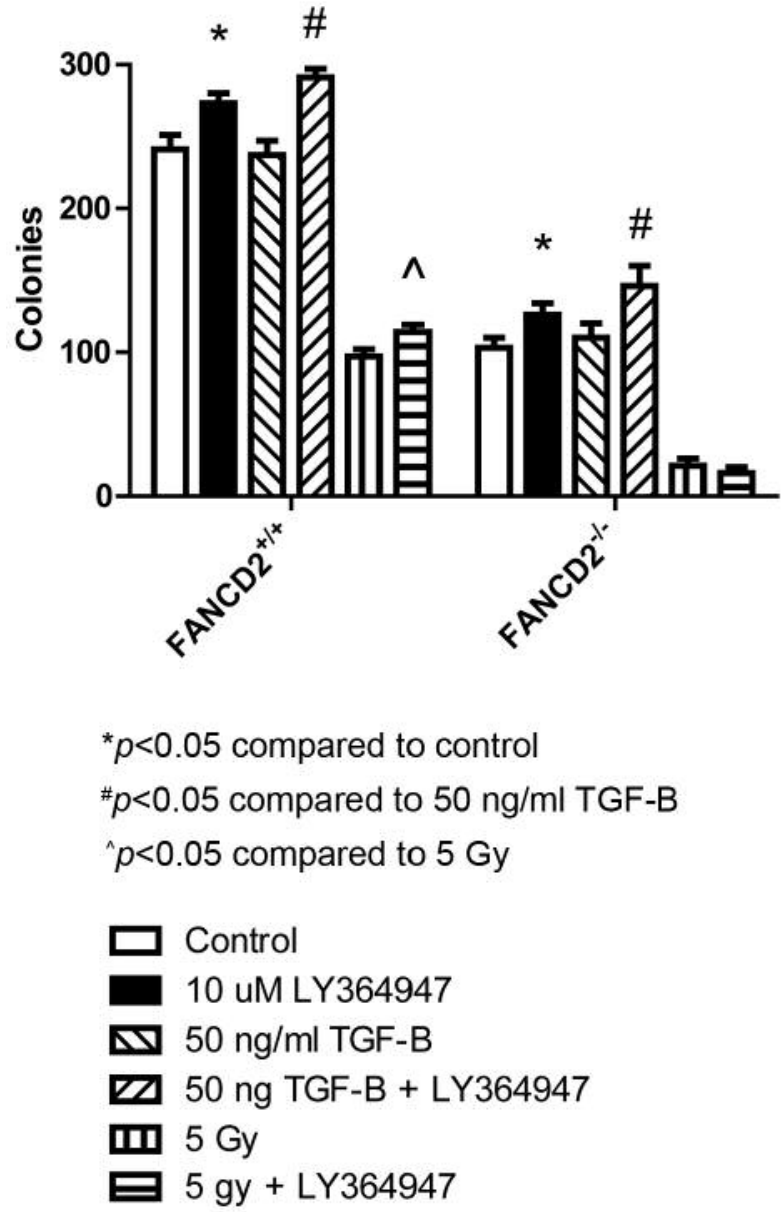

Figure 7. Effect of TGF- $\beta$ receptor antagonist, LY364947 (5 $\mu M)$, on TGF- $\beta$ levels in 5 Gy irradiated or non-irradiated control FANCD2 $2^{-1-}$ or $F A N C 2^{+/+}$fresh explanted mouse bone marrow hematopoietic progenitor cells. FANCD2 $2^{-/}$and FANCD2 $2^{+/+}$marrow was tested for colony formation in semisolid hematopoietic colony supportive medium as described (29).

irradiation increased levels of TGF- $\beta$ both in $F A N C D 2^{-/-}$ mouse bone marrow cells in vitro and in vivo in $F A N C D 2^{-/-}$ mice. The results demonstrate that both $F A N C D 2^{-/-}$and background control C57BL/6NTac mouse bone marrow show increased TGF- $\beta$ in response to cytotoxic agents used in the bone marrow pre-transplant regimen.

The present results also demonstrate that TGF- $\beta$ is induced by each agent in whole bone marrow, and by cells of the hematopoietic microenvironment (bone marrow stromal cells) in both $F A N C D 2^{-/}$and control mice. Previous studies have shown the hyper-responsiveness to TGF- $\beta$ of hematopoietic cells from FA mice and patients with FA (5) suggesting that TGF- $\beta$ elevation following the transplant preparatory regimen may suppress both surviving FA hematopoietic cells and 
donor stem cells. Elevation of TGF- $\beta$ by cytotoxic agents in $F A N C D 2^{-l-}$ marrow may facilitate more efficient clearing of the recipient marrow since those cell populations are more sensitive to TGF- $\beta$. Thus, engrafting donor bone marrow stem cells might have an advantage for homing and proliferation in the TGF- $\beta$ rich microenvironment due to their relative resistance to inhibition by TGF- $\beta$.

In addition to TGF- $\beta$, there is a broad range of ionizing irradiation-induced inflammatory cytokines and stress response gene products in the tissues of wild type, as well as, FANCD2 $2^{-/-}$mice (38-39). Inflammatory cytokines including: TNF- $\alpha$, and IL-1 are induced by irradiation of the oral cavity/oropharyngeal tissue and the irradiated lung (32, 38-39). Other categories of biomarkers that are induced by irradiation include genes for proteins that bind to DNA and act as gene transcription promoters, such as NFk $\beta$, Nrf1, AP1, and SP-1 (32). Whether some of these other induced gene products neutralize, counteract, or synergize with elevated TGF- $\beta$ in FA patients to either suppress or exacerbate the hyperactive TGF- $\beta$ responses and how these other gene products relate to the specific categories of toxicity in bone marrow transplant recipients is unknown.

The present data establish that the radiation mitigator drugs, JP4-039 (27-31) and MMS350 (32-33), each modulate the induction of TGF- $\beta$ by cytotoxic agents in cell lines in vitro. The TGF- $\beta$ inhibitor, LY364947 also modulated irradiation or drug induced TGF- $\beta$ in vitro with fresh marrow hematopoietic colony forming cells. Production of TGF- $\beta$ by irradiated or cytotoxic drug treated bone marrow stromal cells from $F A N C D 2^{-/-}$mice demonstrates that the bone marrow in the post-transplant FA patient may continue to be a source of inhibition of hematopoietic stem cells. This phenomenon may decrease stable donor bone marrow engraftment in FA patients, and limit survival of residual recipient marrow. Continued elevation of TGF- $\beta$ may contribute to late effects in post-transplant FA patients including: organ failure (9), carcinogenesis (10-12), and susceptibility to infectious agents (13). Further studies will be required to establish the need for adding to FA marrow transplant recipient's therapeutic agents, which abrogate the induction of TGF- $\beta$.

\section{Acknowledgements}

This study was supported by NIAID/NIH U19-A1068021 and a grant from the Fanconi Anemia Research Fund. This project used the UPCI animal facility that is supported in part by award P30CA047904.

\section{References}

1 Mudra KK, Morris C, DeLaat C, Sambrano J, Masterson M, Mueller R, Shahidi NT, Yanik G, Desantes K, Friedman DJ, Auerbach AD and Harris RE: Bone marrow transplantation in Fanconi Anemia using matched sibling donors. Blood 84: 2050-2054, 1994.
2 Gluckman E, Auerbach AD, Horowitz MM, Sobocinski KA, Ash RC, Bortin MM, Butturini A, Camitta BM, Champlin RE, Friedrich W, Good RA, Gordon-Smith EC, Harris RE, Klein JP, Ortega JJ, Pasquini R, Ramsay NK, Speck B, Vowels MR, Zhang MJ and Gale RP: Bone marrow transplantation for Fanconi anemia. Blood 86: 2856-2862, 1995.

3 MacMillan ML and Wagner JE: Haematopoietic cell transplantation for Fanconi anemia - when and how? Br J Haematol 149: 14-21, 2010.

4 Kutler DI, Singh B, Satagopan J, Batish SD, Berwick M, Giampietro PF, Hanenberg H, and Auerbach AD: A 20-year perspective on the International Fanconi Anemia Registry (IFAR). Blood 101: 1249-1256, 2003.

5. Zhang H, Kozono DE, O'Connor KW, Vidal-Cardenas S, Rousseau A, Hamilton A, Moreau L, Gaudiano EF, Greenberger J, Bagby G, Soulier J, Grompe M, Parmar K and D'Andrea AD: TGF- $\beta$ inhibition rescues hematopoietic stem cell defects and bone marrow failure in Fanconi Anemia. Cell Stem Cell 18: 1-14, 2016.

6 Bernardo ME and Aiuti A: The role of conditioning in hematopoietic stem-cell gene therapy. Human Gene Therapy 27(10): 741-785, 2016

7 Auerbach AD and Allen RG: Leukemia and preleukemia in Fanconi anemia patients. A review of the literature and report of the International Fanconi Anemia Registry. Cancer Genet Cytogenet 51: 1-12, 1991.

8 Alter BP, Greene MH, Velazquez I and Rosenberg PS: Cancer in Fanconi anemia. Blood 101: 2072, 2003.

9 Alter BP: Fanconi anemia and malignancies. Am J Hematol 53: 99-110, 1996.

10 Rosenberg PS, Socie G, Alter BP and Gluckman E: Risk of head and neck squamous cell cancer and death in patients with Fanconi anemia who did and did not receive transplants. Blood 105: 67-73, 2005.

11 D'Andrea AD: Susceptibility pathways in Fanconi's anemia and breast cancer. N Engl J Med 362: 1909-1919, 2010.

12 Masserot C, Peffault de Latour R, Rocha V, Leblanc T, Rigolet A, Pascal F, Janin A, Soulier J, Gluckman E and Socie G: Head and neck squamous cell carcinoma in 13 patients with Fanconi anemia after hematopoietic stem cell transplantation. Cancer 113: 3315-3322, 2008 .

13 Lowy DR and Gillison ML: A new link between Fanconi anemia and human papillomavirus-associated malignancies. J Natl Cancer Inst 95: 1648-1650, 2003.

14 Sasaki MS, and Tonomura A: A high susceptibility of Fanconi anemia to chromosome breakage by DNA cross-linking agents. Cancer Res 33: 1829-1836, 1973.

15 Parmar K, Kim J, Sykes SM, Shimamura A, Stuckert P, Zhu K, Hamilton A, Deloach MK, Kutok JL, Akashi K, Gilliland DG and D'Andrea A: Hematopoietic stem cell defects in mice with deficiency of FANCD2 or Usp1. Stem Cells 28: 1186-1195, 2010.

16 Ohta M, Greenberger JS, Anklesaria P, Bassols A and Massague $\mathrm{J}$ : Two forms of transforming growth factor- $\beta$ distinguished by multipotential haematopoietic progenitor cells. Nature 329: 539$541,1987$.

17 Anklesaria P, Kase KR, Glowacki J, Holland CH, Sakakeeny MA, Wright JH, FitzGerald TJ, Lee C-YL and Greenberger JS: Engraftment of a clonal bone marrow stromal cell line in vivo stimulates hematopoietic recovery form total body irradiation. Proc Natl Acad Sci, USA 84: 7681-7685, 1987. 
18 Epperly MW, Travis EL, Sikora C and Greenberger JS: Magnesium superoxide dismutase (MnSOD) plasmid/liposome pulmonary radioprotective gene therapy: Modulation of irradiation-induced mRNA for Il- 1, TNF- $\alpha$, and TGF- $\beta$ correlates with delay of organizing alveolitis/fibrosis. Biology of Blood and Marrow Transplantation 5: 204-214, 1999.

19 Zhou S, Lechpammer S, Greenberger J and Glowacki J: Hypoxia inhibition of adipocytogenesis in human bone marrow stromal cells requires TGF- $\beta / \mathrm{Smad} 3$ signaling. J Biol Chem 280(4): 22688-22696, 2005.

20 Epperly MW, Cao S, Goff J, Shields D, Zhou S, Glowacki J and Greenberger J: Increased longevity of hematopoiesis in continuous bone marrow cultures and adipocytogenesis in marrow stromal cells derived from SMAD3 ${ }^{-1-}$ mice. Exp Hematol 33: 353-362, 2005.

21 Epperly MW, Franicola D, Zhang X, Nie S, Wang H, Bahnson A, Shields D, Goff J, Shen H and Greenberger JS: Reduced irradiation pulmonary fibrosis and stromal cell migration in SMAD3-/- marrow chimeric mice. In Vivo 20: 573-582, 2006.

22 Epperly MW, Goff J, Zhang X, Shields D, Wang H, Shen H, Franicola D, Bahnson A, Greenberger EE and Greenberger JS: Increased radioresistance, G2M checkpoint inhibition, and impaired migratory capacity of bone marrow stromal cell lines derived form SMAD3-/- mice. Radiat Res 165: 671-677, 2006.

23 Fujita T, Epperly MW, Zou H, Greenberger JS and Wan Y: Regulation of the APC-separase cascade by TGF- $\beta$ modulates mitotic progression in BMSC. Molec Cell Biol 19: 5446-5455, 2008.

24 Alatrash G, Thall PF, Valdez BC, Fox PS, Ning J, Garber HR, Janbey S, Worth LL, Popat U, Hosing C, Alousi AM, Kebriaei P, Shpall EJ, Jones RB, de Lima M, Rondon G, Chen J, Champlin $\mathrm{RE}$ and Andersson BS: Long-term outcomes after treatment with clofarabine \pm fludarabine with once-daily intravenous Busulfan as pretransplant conditioning therapy for advanced myeloid leukemia and myelodysplastic syndrome. Biology of Blood and Marrow Transplantation 22: 1792-1800, 2016.

25 Kennedy VE, Savani BN, Greer JP, Kassim AA, Engelhardt BG, Goodman SA, Sengsayadeth S, Chinratanalab W and Jagasia M: Reduced-intensity conditioning with fludarabine, cyclophosphamide, and rituximab is associated with improved outcomes compared with fludarabine and Busulfan after allogeneic stem cell transplantation for B cell malignancies. Biology of Blood and Marrow Transplantation 22: 1801-1807, 2016.

26 Zhang QS, Eaton L, Snyder ER, Houghtaling S, Mitchell JB, Finegold M, Van Waes C and Grompe M: Tempol protects against oxidative damage and delays epithelial tumor onset in Fanconi anemia mice. Cancer Res 68: 1601-1608, 2008.

27 Fink M, Macias CA, Xiao J, Tyurina YY, Delude RL, Greenberger JS, Kagan VE and Wipf P: HemigramicidinTEMPO conjugates: Novel mitochondria-targeted antioxidants. Crit Care Med 35(9): 5461-5470, 2007.

28 Rajagopalan MS, Gupta K, Epperly MW, Franicola D, Zhang X, Wang H, Zhao H, Tyurin VA, Kagan VE, Wipf P, Kanai A and Greenberger JS: The mitochondria-targeted nitroxide JP4-039 augments potentially lethal irradiation damage repair. In Vivo 23: 717-726, 2009.

29 Goff JP, Epperly MW, Shields D, Wipf P, Dixon T and Greenberger JS: Radiobiologic effects of GS-nitroxide (JP4-039) in the hematopoietic syndrome. In Vivo 25: 315-324, 2011.

30 Rwigema J-CM, Beck B, Wang W, Doemling A, Epperly MW, Shields D, Franicola D, Dixon T, Frantz M-C, Wipf P, Tyurina Y,
Kagan VE, Wang H and Greenberger JS: Two strategies for the development of mitochondrial-targeted small molecule radiation damage mitigators. Int J Radiat Oncol Biol Phys 80(3): 860-868, 2011.

31 Shinde A, Epperly MW, Franicola D, Cao S, Goff J, Shields D, Franicola D, Wipf P, Wang $\mathrm{H}$ and Greenberger JS: Increased longevity of GS-nitroxide (JP4-039) treated mouse long-term bone marrow cultures and radioresistance of derived bone marrow stromal cell lines. In Vivo 28(5): 699-708, 2014.

32 Kalash R, Epperly MW, Goff J, Dixon T, Sprachman MM, Zhang X, Shields D, Cao S, Wipf P, Franicola D, Berhane H and Greenberger JS: Amelioration of irradiation pulmonary fibrosis by a water-soluble bi-functional sulfoxide radiation mitigator (MMS350). Radiat Res 180: 474-490, 2013.

33 Shinde A, Epperly MW, Cao S, Franicola D, Shields D, Wang H and Greenberger JS: Effects of the radiation mitigator bifunctional sulfoxide MMS350 on hematopoiesis and long-term bone marrow cultures. In Vivo 28: 457-466, 2014.

34 Berhane H, Epperly MW, Goff J, Kalash R, Cao S, Franicola D, Zhang X, Shields D, Houghton F, Wang H, Sprachman M, Wipf P, Li S, Gao X, Parmar K and Greenberger JS: Radiobiologic differences between bone marrow stromal and hematopoietic progenitor cell lines from Fanconi anemia (FANCD2-I- mice. Radiat Res 181: 76-89, 2014.

35 Keppel K, Epperly MW, Shields D, Hou W, Franicola D, Zhang $\mathrm{X}$, Fisher R and Greenberger JS: Radiation resistance of double knockout (DKO) Smad3 ${ }^{-/-}$FANCD2 ${ }^{-/-}(129 / \mathrm{Sv})$ mouse bone marrow stromal cell lines. Blood 128: 3901, 2016.

36 Epperly MW, Sikora C, Defilippi S, Gretton J, Zhan Q, Kufe DW and Greenberger JS: MnSOD inhibits irradiation-induced apoptosis by stabilization of the mitochondrial membrane against the effects of SAP kinases p38 and Jnk1 translocation. Radiat Res 157: 568-577, 2002.

37 Zhang YE: Non-Smad pathways in TGF- $\beta$ signaling. Cell Research 19: 128-139, 2009.

38 Berhane H, Shinde A, Kalash R, Xu K, Epperly MW, Goff J, Franicola D, Zhang X, Dixon T, Shields D, Wang H, Wipf P, Li S, Gao $X$ and Greenberger JS: Amelioration of irradiation induced oral cavity mucositis and distant bone marrow suppression in FANCD2-/- $(\mathrm{FVB} / \mathrm{N})$ mice by intraoral JP4039/F15. Radiat Res 182: 35-49, 2014.

39 Shinde A, Berhane H, Rhieu BH, Kalash R, Xu K, Goff J, Epperly MW, Franicola D, Zhang X, Dixon T, Shields D, Wang H, Wipf P, Parmar K, Ferris R, Li S and Greenberger JS: Intraoral mitochondrial-targeted GS-nitroxide, JP4-039, radioprotects normal tissue in tumor-bearing radiosensitive FANCD2 $2^{-/-}$(C57BL/6) mice. Radiat Res 185: 134-150, 2016.

40 Kim H, Epperly MW, Flickinger J Jr., Bernard M and Greenberger JS: The pro-autophagy drug, Carbamazepine, is a radiation protector and mitigator. Int J Radiat Biol 87(10): 1052-1060, 2011.

Received October 28, 2016

Revised January 26, 2017

Accepted January 31, 2017 